\title{
Study of Quinizarin Interaction with SDS Micelles as a Model System for Biological Membranes
}

\author{
Ana Maria Toader, ${ }^{1}$ Petruta Oancea ${ }^{2}$ and Mirela Enache ${ }^{1, *}$ \\ ${ }^{1}$ Institute of Physical Chemistry Ilie Murgulescu, Romanian Academy, Splaiul Independentei 202, \\ Bucharest 060021, Romania \\ ${ }^{2}$ Department of Physical Chemistry, University of Bucharest, Blvd. Elisabeta 4-12, Bucharest 030018, Romania \\ *Corresponding author: E-mail: enachemir@yahoo.com
}

Received: $10-21-2019$

\begin{abstract}
Investigation of the interaction of quinizarin $(\mathrm{Q})$, an analogue of the core unit of different anticancer drugs, with anionic SDS micelles has been performed by absorption and conductance measurements in $0.1 \mathrm{M}$ phosphate buffer, $\mathrm{pH} 7.4$ and over the temperature range of 293.15-323.15 K. The values of binding constant $\left(\mathrm{K}_{\mathrm{b}}\right)$, partition coefficient $\left(\mathrm{K}_{\mathrm{x}}\right)$ and the corresponding thermodynamic parameters (Gibbs free energy, enthalpy, entropy) for the binding and distribution of quinizarin between the bulk aqueous solution and surfactant micelles have been determined and discussed in terms of possible intermolecular interactions. Values of critical micelle concentration (CMC) and degree of ionization ( $\alpha$ ) for SDS in the absence and the presence of quinizarin have been evaluated from conductometric study. Comparing the absorption spectra of quinizarin in SDS micelles with the spectra in different solvents revealed that quinizarin molecules are located in the hydrophilic region of SDS micelles. The trend of changes in Gibbs free energy, enthalpy and entropy with temperature shows that both binding and partition processes are spontaneous and entropy driven. In addition, the hydrophobic interactions are the main forces involved in binding and partition processes.
\end{abstract}

Keywords: Quinizarin; SDS micelles; binding constant; partition coefficient

\section{Introduction}

Quinizarin (1,4-dihydroxy-9,10-anthraquinone, Q) belongs to the synthetic anthraquinones which are known for their antifungal, antibacterial and antioxidant properties. ${ }^{1,2}$ Quinizarin is also an interesting molecule from a pharmaceutical point of view; this chromophore framework is the main part in the structure of anticancer drugs such as doxorubicin, daunorubicin, and mitoxantrone which are widely used in clinical practice. These drugs exhibit their antitumor activity by intercalation of the aromatic moiety between the DNA base pairs, resulting in the inhibition of both DNA replication and RNA transcription. ${ }^{3-8}$ Because the biological activity of these drugs is governed by the planar anthraquinone moiety, the interaction of different anthraquinones (quinizarin, danthron, purpurin) with DNA has been already investigated and compared with the established drugs. These studies revealed the different types of binding modes as partial intercalation and hydrogen binding, and binding constants values similar with anthracyclines. ${ }^{9-12}$ In addition to affinity of anthraquinone chromophore toward DNA, the qui-

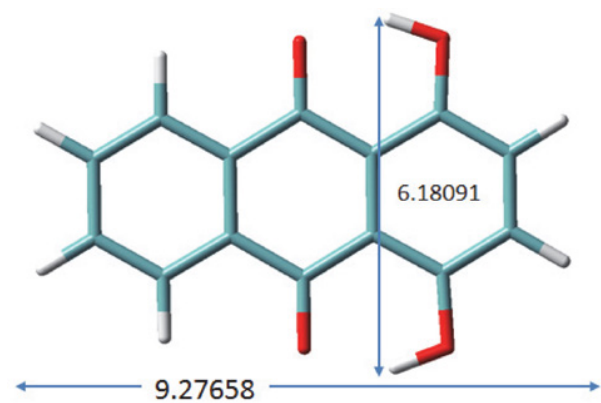

Figure 1. Optimized molecular structure of quinizarin using B3LY$\mathrm{P} / 6-311 \mathrm{G}^{*}$ basis set.

none functionality is involved in generation of reactive oxygen species responsible for the cardiotoxicity of these drugs. ${ }^{13,14}$ Also, quinizarine is commonly used as fuel marker to distinguish the origin and quality of fuels. ${ }^{15}$

As DNA, the main target of anthracycline anticancer drugs is localized in the nucleus of cells they must cross the cell membrane as well the nuclear envelope to obtain pharmacological activity. Also, in eukaryotic cells the drug 
molecules may interact with membranes of organelles such as the endoplasmic reticulum, the Golgi and the mitochondria once they are released into the cytosol. Therefore, the understanding of the interactions between anticancer drugs and cellular membranes is of primary importance because these interactions are related with drug transport, accumulation and pharmacological activity. ${ }^{16}$ Although the cellular and nuclear membranes are not the primary target of the anthraquinone anticancer drugs, interactions between drug molecules and membrane lipids may induce profound alterations in cell functions like transient increase in membrane fluidity, correlated with ceramide generation and the fusion of membrane lipid rafts leading to activation of the apoptotic cascade. ${ }^{17}$ As the anthraquinone chromophore of quinizarin is the major part in the structure of these anticancer drugs, it can be inferred that the similar major effects are expected to be induced by quinizarin at the level of biological membranes. These interactions are very difficult to investigate because of the complexity of structure and functions of biological membranes. Therefore, different simplified model membranes composed by a hydrophobic core and hydrophilic surface have gained a significant role in research as alternatives for biological membranes. Micelles are colloidal-sized aggregates of surfactants at concentrations higher than critical micelle concentration (CMC). The structural similarity of micelles with biological membranes allows them to be used as simple model system to conduct in vitro study of drug-membrane interactions. ${ }^{18-23}$ Besides, the micelles can solubilize poorly soluble drugs and can be used as drug carriers in different drug delivery systems. ${ }^{24}$ Micelles with their hydrophobic core and hydrophilic interface region mimic biological membranes and are able to account for both hydrophobic and hydrophilic (hydrogen bonds, electrostatic and dipole-dipole) interactions, which occur during the interaction of different drugs with biological membranes. ${ }^{25,26}$

Taking into account that the planar anthraquinone unit of quinizarin plays a key role in pharmacological activity of different anticancer drugs and that the surfactant micelles are accepted as simple model systems for studying different aspects of drug molecules interactions with biological membranes, in the present paper the interaction of quinizarin with SDS micelles was studied by employing absorption and conductometric techniques. The binding constant, partition coefficient and thermodynamic parameters for both binding and partition processes were calculated. These quantitative results would further help as a basic knowledge for the design of more efficient drug delivery systems.

\section{Material and Methods}

\section{1. Materials}

Quinizarin (96\% purity), SDS and other chemicals were purchased from Sigma Aldrich and employed as re- ceived without further purification. Experiments were performed in $0.1 \mathrm{M}$ phosphate buffer ( $\mathrm{pH} 7.4)$ and deionized water (Mili-Q water purification system) was used for the preparation of solutions. A concentrated $(2 \mathrm{mM})$ stock solution of quinizarin was prepared by dissolving appropriate amount of compound in methanol. Then, a small aliquot of that stock was diluted with phosphate buffer. Methanol content in the investigated solutions was always below $1 \%$. The solutions were kept in the dark due to quinone moiety being sensitive to light.

\section{2. Apparatus and Methods}

Spectrophotometric measurements were made on a JASCO V-630 spectrophotometer equipped with a Peltier-controlled ETCR-762 model accessory (JASCO Corporation, Tokyo, Japan) using a matched pair of quartz cuvettes with a path length of $1 \mathrm{~cm}$. The absorption spectra of pure quinizarin in $0.1 \mathrm{M}$ phosphate buffer ( $\mathrm{pH}$ 7.4) and in the presence of different concentrations of SDS have been recorded in the temperature range of $293.15-323.15 \mathrm{~K}$ with an increment of $10 \mathrm{~K}$ interval, in the wavelength range of $350-700 \mathrm{~nm}$. The absorption titration experiments were performed by successive additions of concentrated surfactant stock solution directly into a cuvette containing $2 \mathrm{ml}$ of quinizarin solution. After addition of surfactant aliquots, the mixtures were gentle shaken and the absorption spectra were registered after 3 minutes of equilibration.

Specific conductivities were measured with Consort K912 conductivity meter (Parklaan 36, B-2300 Turnhout, Belgium). This instrument has auto ranging from 0 to 1000 $\mathrm{mS} / \mathrm{cm}$ and conductivity control with accuracy of $\pm 0.5 \%$. The electrodes used have a cell constant of $0.98 \mathrm{~cm}^{-1}$. The conductivity runs were carried out by gradually adding small amounts $(20 \mu \mathrm{l})$ of a concentrated solution of SDS into $0.1 \mathrm{M}$ phosphate buffer ( $\mathrm{pH} 7.4$ ), in the absence and the presence of quinizarin.

\section{Results and Discussion}

\section{1. Absorption Spectral Characteristics of Quinizarin in the Presence of SDS}

The absorption spectra of quinizarin in the absence and in the presence of various concentrations of SDS in 0.1 M phosphate buffer ( $\mathrm{pH} 7.4$ ) at $293.15 \mathrm{~K}$ and $313.15 \mathrm{~K}$ are given in Fig. 2. The $\mathrm{pK}_{\mathrm{a}}$ values of quinizarin are reported to be $\mathrm{pK}_{1}=10.15$ and $\mathrm{pK}_{2}=13.19$, therefore quinizarin can exist in neutral, monodeprotonated and dideprotonated forms as a function of $\mathrm{pH}$. Also, the deprotonation produces significant changes in the visible absorption spectrum of quinizarin. ${ }^{27}$ At $\mathrm{pH}$ 7.4, quinizarin exists in neutral form and the visible absorption spectrum shows a broad absorption maximum at $\sim 470 \mathrm{~nm}$ and a shoulder at about $520 \mathrm{~nm}$. It can be seen from Fig. 2 that the absorption 

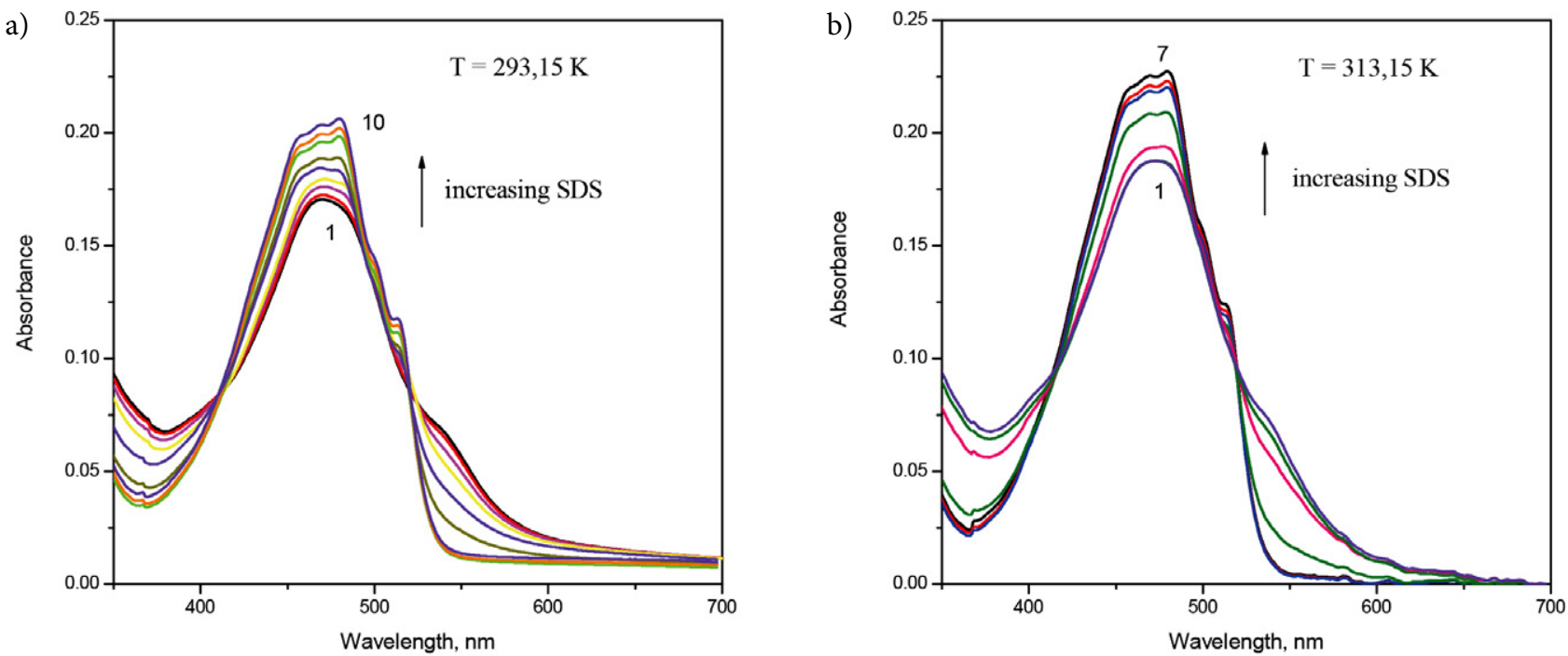

Figure 2. Absorption spectra of $1.80 \times 10^{-5} \mathrm{M}$ quinizarin in $0.1 \mathrm{M}$ phosphate buffer ( $\mathrm{pH}$ 7.4) in the absence (spectrum 1) and in the presence of increasing amounts of SDS: (a) $\mathrm{T}=293.15 \mathrm{~K}$; (b) $\mathrm{T}=313.15 \mathrm{~K}$.

maximum of quinizarin increases as the SDS concentration enhances. Moreover, with increasing SDS concentrations the absorption maximum is split in three peaks, a new peak
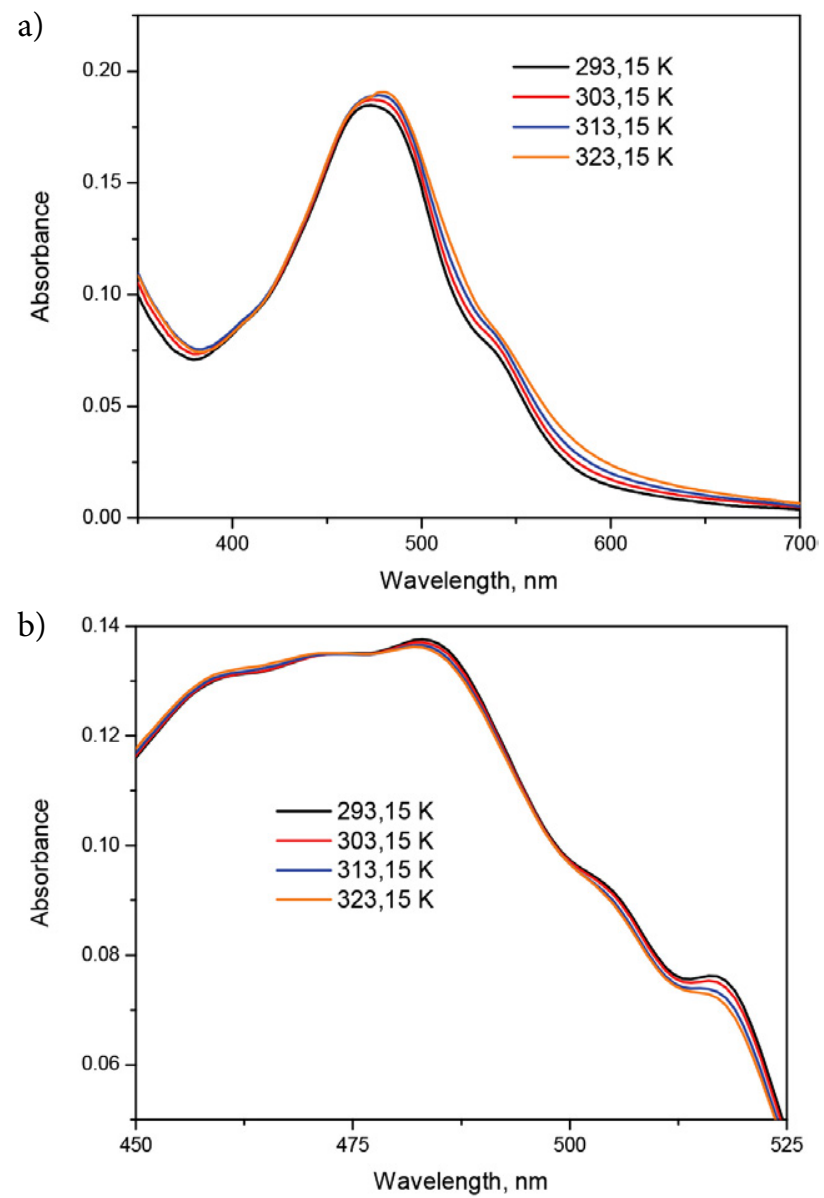

Figure 3. The influence of temperature on: (a) the absorption spectrum of quinizarin and (b) the absorption spectrum of quinizarin incorporated in SDS micelles. appeared around $515 \mathrm{~nm}$ and the shoulder at about $535 \mathrm{~nm}$ disappeared. Also, the addition of SDS yields two isobestic points at $416 \mathrm{~nm}$ and $524 \mathrm{~nm}$. These spectral changes clearly suggest the occurrence of interaction between quinizarin and SDS micelles and the gradual incorporation of quinizarin molecule in SDS micelles. Also, the environment around quinizarin molecules in surfactant micelles is different from bulk aqueous solution as the absorption maxima are red shifted (for about $10 \mathrm{~nm}$ ).

The effect of temperature on the absorption spectra of quinizarin alone and in the presence of SDS micelles is shown in Fig. 3. As seen from Fig. 3(a), the absorbance value of quinizarin increases with increasing temperature from $298.15 \mathrm{~K}$ to $323.15 \mathrm{~K}$ and the absorption maximum is red shifted. In the presence of SDS micelles, the shape of the absorption spectrum is similar for all investigated temperature and the absorption maximum $(483 \mathrm{~nm})$ decreases with increasing temperature (Fig. 3(b)).

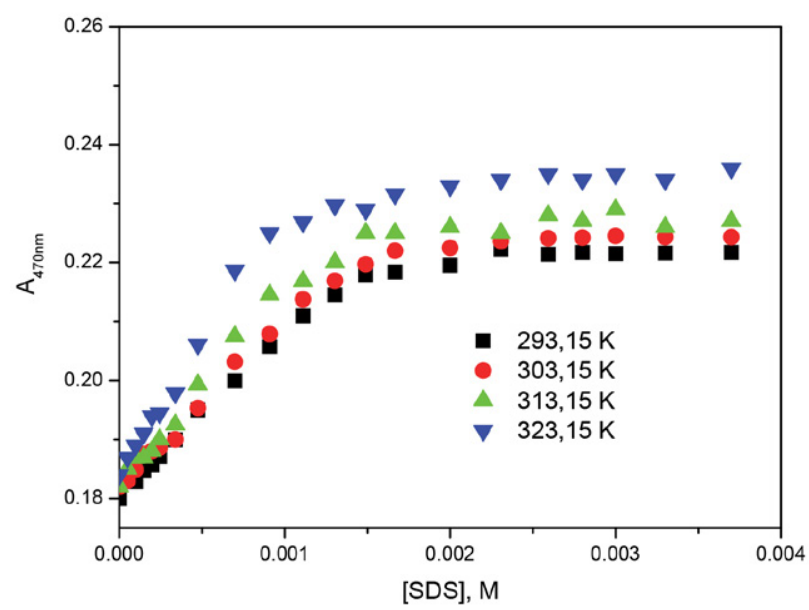

Figure 4. The variation of absorbance with SDS concentration at different temperatures. 
The absorbance of quinizarin in the presence of SDS increases rapidly for SDS concentrations lower than CMC, while in post micellar region the absorbance increases very slowly and becomes almost constant because of the maximum incorporation of drug molecules into micelles (Fig. 4). This spectral behavior is observed for all investigated temperatures but the maximum absorbance increases as the temperature increases for the same SDS concentration.

The CMC of pure SDS in $0.1 \mathrm{M}$ phosphate buffer $(\mathrm{pH}$ $7.4)$ at $293.15 \mathrm{~K}$ was determined from conductivity measurements (see Conductivity studies paragraph) and it is $9.28 \times 10^{-4} \mathrm{M}$. This value is smaller than the CMC of SDS in water $\left(8.08 \times 10^{-3} \mathrm{M}\right)$ and is an agreement with literature data, which indicate that the CMC value decreases in phosphate buffer as the concentration of electrolyte increases (from $6.09 \times 10^{-3} \mathrm{M}$ in $5 \mathrm{mM}$ electrolyte concentration to $1.99 \times 10^{-3} \mathrm{M}$ in $50 \mathrm{mM}$ electrolyte concentration). ${ }^{28}$

\section{2. Determination of Binding Constant}

The quantification of the degree of the interaction of quinizarin with SDS micelles was made by determination of the binding constant $\left(\mathrm{K}_{\mathrm{b}}\right)$ and micelle-water partition coefficient $\left(\mathrm{K}_{\mathrm{x}}\right)$ at different temperatures. These parameters were determined from the absorbance values at 470 $\mathrm{nm}$ of series of solutions containing a fixed quinizarin concentration and increasing surfactant concentrations.

The binding constant $\left(\mathrm{K}_{\mathrm{b}}\right)$ was estimated from the Benesi-Hildebrand equation: ${ }^{29,30}$

$$
\frac{1}{A-A_{0}}=\frac{1}{K_{\mathrm{b}}\left(A_{1}-A_{0}\right)[S D S]_{\mathrm{m}}}+\frac{1}{A_{1}-A_{0}}
$$

where $[\mathrm{SDS}]_{\mathrm{m}}$ is the concentration of the micellized SDS $\left([\mathrm{SDS}]_{\mathrm{m}}=[\mathrm{SDS}]-\mathrm{CMC}\right), \mathrm{A}_{0}, \mathrm{~A}, \mathrm{~A}_{\max }$ are the absorbance in the absence of, at intermediate concentration, and at high concentration of SDS, respectively. The plot of $1 /$ (A $\left.-\mathrm{A}_{0}\right)$ vs. $1 /[\mathrm{SDS}]$ gives straight lines for all investigated temperatures (Fig. 5), which further indicates the formation of a 1:1 complex between quinizarin and SDS micelles. The values of the binding constant obtained from the ratio of the intercept to the slope of the Benesi-Hildebrand plots (Fig. 5) are presented in Table 1. It can be ob-

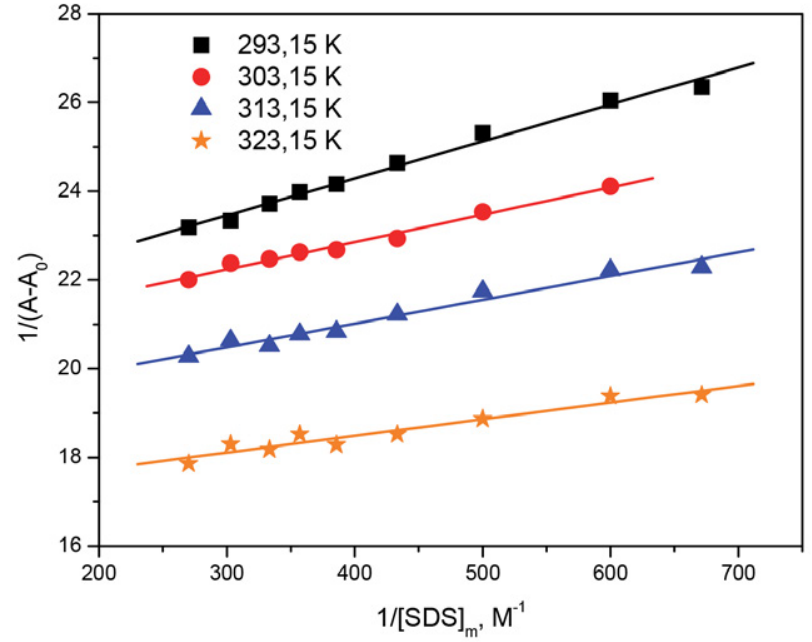

Figure 5. Plot of $1 /\left(\mathrm{A}-\mathrm{A}_{0}\right)$ versus $1 /[\mathrm{SDS}]_{\mathrm{m}}$ for the interaction of quinizarin with SDS micelles at various temperatures.

served that the binding constant increases with increasing temperatures.

Comparing the values of the binding constants at $293.15 \mathrm{~K}$ for the interaction of quinizarin with SDS micelles with those for the interaction of mitoxantrone ${ }^{25,31}$ or epirubicin ${ }^{21}$ with SDS micelles, it is clear that the interaction of quinizarin with SDS micelles is stronger than the interaction of mitoxantrone or epirubicin with SDS micelles. Mitoxantrone is a synthetic anthracenedione anticancer drug, which at $\mathrm{pH} 7.4$ exists as di-cation with two positive charges on the nitrogen atoms from the side chains, while epirubicin has one positive charge localized at protonated amino nitrogen on the sugar moiety. In spite of positive charges of mitoxantrone and epirubicin and electrostatic attractions for negatively charged SDS micelles, these drugs exhibit smaller binding constants than neutral quinizarin. A possible explanation for the stronger interaction of quinizarin with SDS micelles than that of mitoxantrone or epirubicin could be the smaller size of quinizarin which leads to a better accommodation of quinizarin molecules into SDS micelles. This explanation is supported by our previous results which indicate higher binding constants for the interaction of mitoxantrone with SDS micelles at $\mathrm{pH} 10$ (when mitoxantrone molecule is uncharged) in comparison with $\mathrm{pH} 7.4$ when mitoxantrone is positively charged. ${ }^{31}$

Table 1. Binding constant, partition coefficient and corresponding standard thermodynamic parameters for the interaction of quinizarin with SDS micelles.

\begin{tabular}{|c|c|c|c|c|c|c|c|c|}
\hline $\begin{array}{c}\mathrm{T} \\
(\mathrm{K})\end{array}$ & $\begin{array}{c}\mathbf{K}_{\mathbf{b}} \\
\left(\mathbf{M}^{-1}\right)\end{array}$ & $\begin{array}{c}\Delta \mathrm{G}_{\mathrm{b}}^{0} \\
\left(\mathrm{~kJ} \mathrm{~mol}^{-1}\right)\end{array}$ & $\begin{array}{c}\Delta \mathrm{H}_{\mathrm{b}}^{0} \\
\left(\mathrm{~kJ} \mathrm{~mol}^{-1}\right)\end{array}$ & $\begin{array}{c}\Delta S_{\mathrm{b}}^{0} \\
\left(\mathrm{~J} \mathrm{~mol}^{-1} \mathrm{~K}^{-1}\right)\end{array}$ & $\begin{array}{c}\mathrm{K}_{\mathrm{x}} / 10^{5} \\
\left(\mathrm{M}^{-1}\right)\end{array}$ & 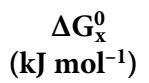 & $\begin{array}{c}\Delta \mathrm{H}_{\mathrm{x}}^{0} \\
\left(\mathrm{~kJ} \mathrm{~mol}^{-1}\right)\end{array}$ & $\begin{array}{c}\Delta S_{\mathrm{x}}^{0} \\
\left(\mathrm{~J} \mathrm{~mol}^{-1} \mathrm{~K}^{-1}\right)\end{array}$ \\
\hline 293.15 & $2524 \pm 0.05$ & -19.08 & 14.34 & 114.00 & $3.44 \pm 0.08$ & -31.06 & 16.84 & 163.40 \\
\hline 303.15 & $3290 \pm 0.09$ & -20.40 & & 114.60 & $4.74 \pm 0.07$ & -32.92 & & 164.14 \\
\hline 313.15 & $3520 \pm 0.09$ & -21.25 & & 113.65 & $5.26 \pm 0.08$ & -34.28 & & 163.24 \\
\hline 323.15 & $4530 \pm 0.08$ & -22.61 & & 114.34 & $6.77 \pm 0.09$ & -36.05 & & 163.67 \\
\hline
\end{tabular}


Based on these results, we can say that the hydrophobic interactions play a major role in the binding of quinizarin to SDS micelles. Studies performed by Das and co-workers established that the hydrophobic interaction plays a crucial role in the binding of 2-amino-3-hydroxy-anthraquinone to SDS micelles, while the hydrophilic interaction plays an important role in its interaction with CTAB micelles. ${ }^{32}$

\section{3. Determination of Partition Coefficient}

Partition coefficient $\left(\mathrm{K}_{\mathrm{x}}\right)$ was evaluated from the following equation, according to the pseudo-phase model: 33,34

$$
\frac{1}{\Delta A}=\frac{1}{\Delta A_{\infty}}+\frac{n_{\mathrm{W}}}{K_{\mathrm{x}} \Delta A_{\infty}\left([S D S]+C_{\mathrm{T}}-C M C\right)}
$$

where $\Delta \mathrm{A}=\mathrm{A}-\mathrm{A}_{0}, \Delta \mathrm{A}_{\infty}=\mathrm{A}_{1}-\mathrm{A}_{0}, \mathrm{C}_{\mathrm{T}}$ is the total drug concentration and $n_{w}=55.5 \mathrm{M}$ is the molarity of water. The value of $\mathrm{K}_{\mathrm{x}}$ is obtained from the slope of the plot of $1 /$ $\Delta \mathrm{A}$ versus $1 /\left(\mathrm{C}_{\mathrm{T}}+[\mathrm{SDS}]-\mathrm{CMC}\right)$ as shown in Fig. 6 for different temperatures. This relation is linear for very high surfactant concentrations and the curve tends to bend upwards for decreasing surfactant concentrations. ${ }^{34}$

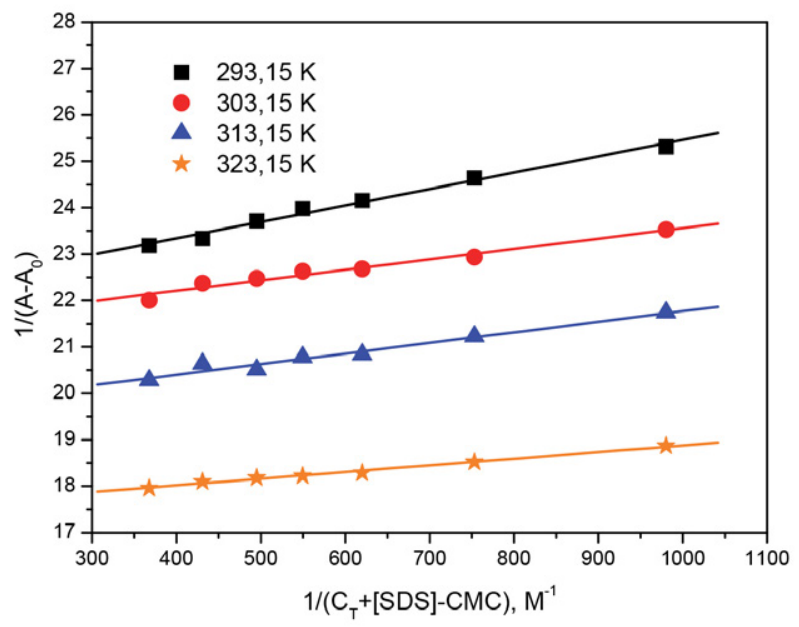

Figure 6. Plot of $1 /\left(A-A_{0}\right)$ versus $1 /\left(C_{T}+[S D S]-C M C\right)$ for the interaction of quinizarin with SDS micelles at various temperatures.

From Table 1 it follows that quinizarin presents large positive values of $\mathrm{K}_{\mathrm{x}}$ indicating that quinizarin molecules prefer to move from aqueous environment to SDS micelles. Moreover, the results show that the partition coefficient increases with the increase in temperature. The values of $\mathrm{K}_{\mathrm{x}}$ obtained for quinizarin are higher than those obtained for the distribution of mitoxantrone in SDS micelles. ${ }^{31}$ This indicates that quinizarin molecules are partitioned in SDS micelles to much greater extent than mitoxantrone. The smaller molecular size of quinizarin molecule in comparison with mitoxantrone allows them to be ac- commodated in palisade layer close to the micelle surface where large space is available and can fit larger number of molecules.

\section{4. Thermodynamic Parameters for the Binding and Partition Processes}

The binding and partition processes for the interaction of quinizarin with SDS micelles were characterized thermodynamically by determining the standard Gibbs free energy of interaction $\left(\Delta \mathrm{G}_{\mathrm{b}}^{0}\right)$ and the standard Gibbs free energy of the transfer of drug from bulk aqueous phase to micellar phase $\left(\Delta \mathrm{G}_{\mathrm{x}}^{0}\right)$, and the corresponding standard enthalpy $\left(\Delta \mathrm{H}^{0}\right)$ and the standard entropy $\left(\Delta \mathrm{S}^{0}\right)$ changes. These parameters, summarized in Table 1 , were calculated from the values obtained for $\mathrm{K}_{\mathrm{b}}$ and $\mathrm{K}_{\mathrm{x}}$ at different temperatures from the spectral studies using the following equations:

$$
\begin{aligned}
& \Delta G^{0}=-R T \ln K \\
& \Delta H^{0}=\frac{\partial\left(\Delta G^{0} / T\right)}{\partial(1 / T)} \\
& \Delta S^{0}=\frac{\Delta H^{0}-\Delta G^{0}}{T}
\end{aligned}
$$

A plot of $\Delta \mathrm{G}^{0} / \mathrm{T}$ versus $1 / \mathrm{T}$ yields a straight line (Fig. 7 ) and the slope of this line is equal to $\Delta \mathrm{H}^{0}$ according to Eq. 4 .

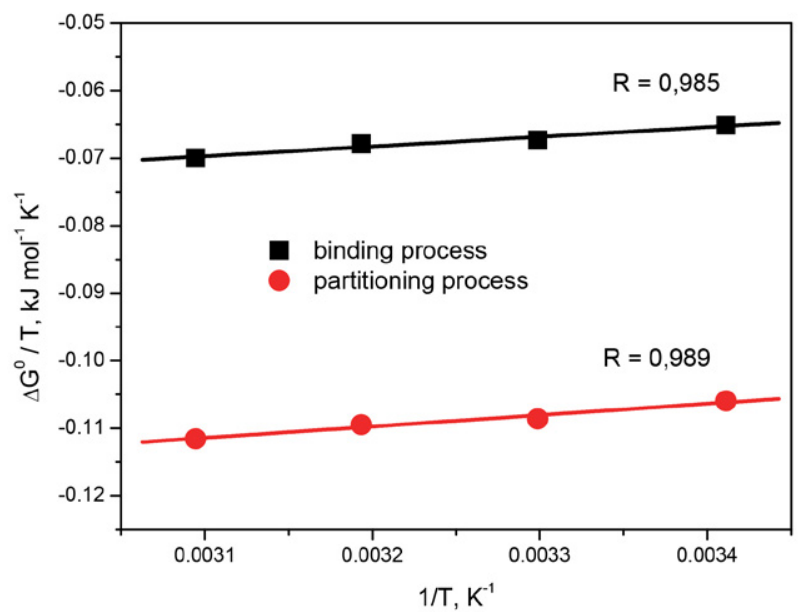

Figure 7. Plot of $\Delta \mathrm{G}^{0} / \mathrm{T}$ versus $1 / \mathrm{T}$ for the binding and partitioning of quinizarin to SDS micelles.

As seen in Table $1, \Delta \mathrm{G}^{0}$ values are negative at each investigated temperature and for both binding and partition processes. These negative values of $\Delta \mathrm{G}^{0}$ indicate the spontaneity of the binding process of quinizarin to SDS micelles and the partition process of qunizarin between the micellar and the bulk aqueous phases. Besides, the $\Delta \mathrm{G}^{0}$ values become more negative with the increase in temperature for 
both binding and partition processes indicating that both processes are more spontaneous at higher temperatures.

The values of $\Delta \mathrm{H}^{0}$ were found to be positive suggesting the endothermic nature of both binding and partition processes. The net $\Delta \mathrm{H}^{0}$ is the sum of the change in enthalpies resulting from hydrophobic interactions, electrostatic interactions, hydration of polar head groups, and counterion binding to micelles. ${ }^{35-37}$ Positive values of $\Delta \mathrm{H}^{0}$ suggest that the hydrophobic interactions are the main forces involved in both binding and partitioning processes. The values of $\Delta S^{0}$ are positive and constant for all investigated temperatures and for both binding and partition processes. The positive values of $\Delta \mathrm{S}^{0}$ and $\Delta \mathrm{H}^{0}$ indicate that both binding and partition processes are entropy controlled over the range of studied temperatures. The endothermic nature of both binding and partition processes accompanied with a strong favorable entropic contribution suggests dominant hydrophobic interactions.

\section{5. Conductometric Studies}

The electrical conductivity measurement was used to determine CMC of SDS in the absence and the presence of quinizarin at $293.15 \mathrm{~K}$. Figure 8 shows the conductance $(\kappa)$ versus surfactant concentration plot obtained for SDS in the absence and in the presence of quinizarin. The values of CMC were estimated as the intersection point between the two straight lines obtained for low and high concentrations of SDS. The results are summarized in Table 2.
It can be observed that the presence of quinizarin increases the CMC of SDS in $0.1 \mathrm{M}$ phosphate buffer from $9.28 \times 10^{-4} \mathrm{M}$ to $1.06 \times 10^{-3} \mathrm{M}$. The increase of the CMC of surfactants was also reported for other different drugs or dyes and it was explained by the possibility of hydrogen bonding between hydrophilic parts of drug and water, as the localization of drug molecules is more probable in the outer portion of micelle close to micelle water interface. This kind of drug solubilization leads to decrease in entropy thus making process of micellization less convenient and increases the CMC. ${ }^{20,35,38}$

The degree of ionization ( $\alpha$ ) of the micelles can be estimated from the ratio of the slopes of the two straight lines above and below the CMC, when the specific conductivity is plotted versus concentration. The degree of counterion association $(\beta)$ is given as $\beta=1-\alpha{ }^{39}$ The reported values for the degree ionization for SDS micelles in aqueous medium are in the range $0.29-0.86$, depending on the experimental technique employed. ${ }^{40,41}$ In our study, the degree of ionization of SDS is 0.23 in $0.1 \mathrm{M}$ phosphate buffer (Table 2) and this value is smaller than the reported values in aqueous solution. In phosphate buffer, the salts of phosphates ionize in solution and the sodium ions tend to condense onto the micelle surface. This leads to a decrease of the ionization degree and an increase in the aggregation number and microviscosity. ${ }^{42}$ The presence of quinizarin leads to an increase of the degree of ionization. This can be explained by the location of quinizarin in the palisade layer of the micelles leading to a steric hindrance to the bind-

Table 2. Critical micelle concentration (CMC), degree of ionization ( $\alpha$ ) and degree of counterion binding $(\beta)$ for SDS in $0.1 \mathrm{M}$ phosphate buffer ( $\mathrm{pH} 7.4)$ and in the presence of $2.15 \times 10^{-5} \mathrm{M}$ quinizarin at $293.15 \mathrm{~K}$.

\begin{tabular}{lccc}
\hline & CMC, $\mathbf{M}$ & $\boldsymbol{\alpha}$ & $\boldsymbol{\beta}$ \\
\hline SDS & $(9.28 \pm 0.11) \times 10^{-4}$ & $0.230 \pm 0.020$ & $0.770 \pm 0.020$ \\
SDS + quinizarin & $(1.06 \pm 0.08) \times 10^{-3}$ & $0.380 \pm 0.016$ & $0.620 \pm 0.016$ \\
\hline
\end{tabular}

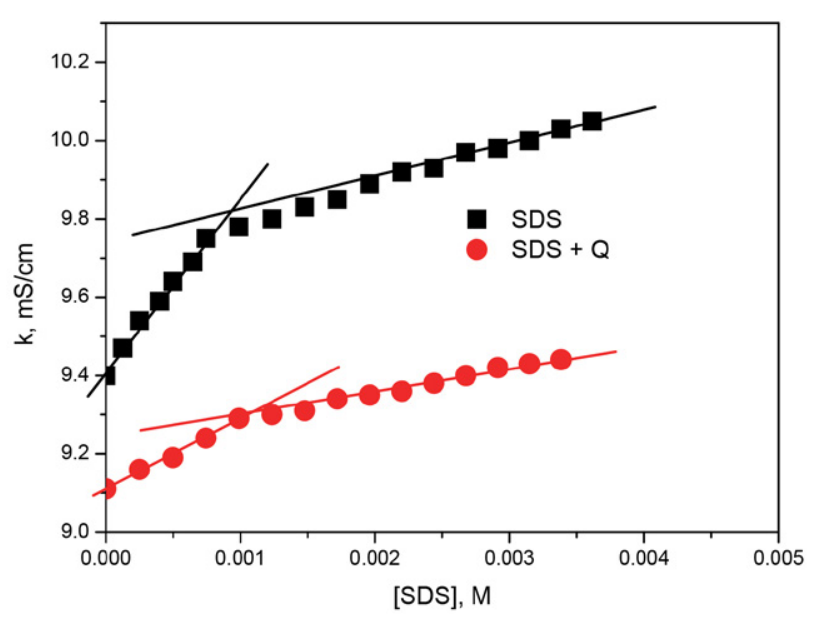

Figure 8. Plots of electrical conductivity versus SDS concentration in the absence and the presence of quinizarin at $293.15 \mathrm{~K}$. ing of counterions to the micelles, facilitating the dissociation of the counterions, which yields higher degree of ionization. ${ }^{43}$ Also, the solubilization of quinizarin in the palisade layer of SDS micelles decreases the surface charge density, facilitating the ionization of the counterions from the head groups of surfactant, and, thereby, yielding higher degree of ionization in the presence of quinizarin. ${ }^{43}$

\section{6. Location of Quinizarin in SDS Micelles}

Drug molecules can interact with surfactant micelles in distinct ways, depending on the hydrophobic character of drugs. They can be adsorbed on the surface of micelles (hydrophilic molecules), entrapped into the hydrocarbon core (hydrophobic molecules) showing a deep penetration) or oriented near the surface in the palisade layer displaying a short penetration..$^{30,44-46}$ The position of incor- 

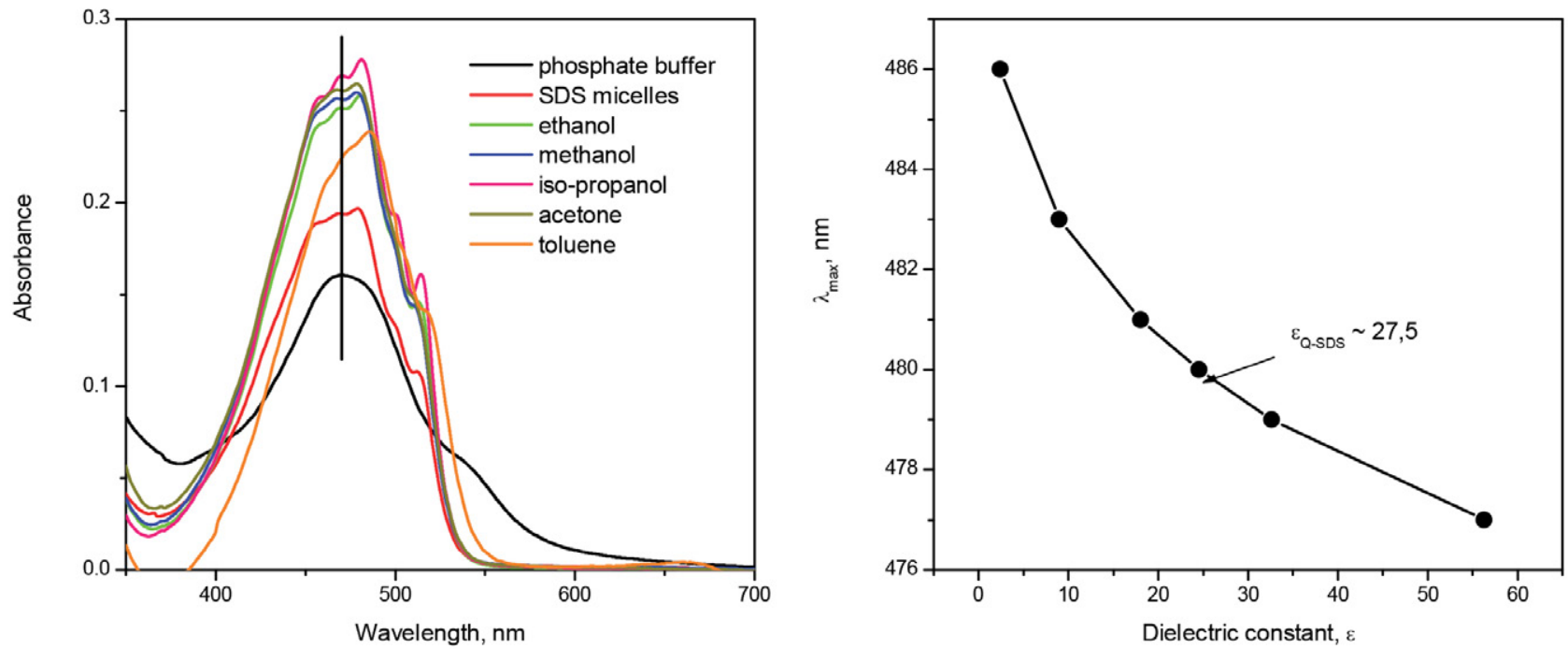

Figure 9. (a) Absorption spectra of quinizarin in different solvents and SDS micelles; (b) Absorption maxima of quinizarin in different solvents as a function of the dielectric constant.

porated molecules into micelles determines the extent of solubilization, the chemical reactivity of the solubilized molecules, and the rate of their release from the micelles and is also a measure of the strength of specific interactions between the solubilized molecules and the micelle (electrostatic or hydrophobic interactions, hydrogen bonds, etc). ${ }^{47}$

Information about the position of quinizarin molecule into SDS micelles was obtained indirectly by comparing the absorption spectrum of the drug in surfactant micelles with the adsorption spectra in solvents with different polarities which mimic the polarity of different parts of the micelles. The spectra of quinizarin in different solvents and SDS micelles are shown in Fig. 9a.

It can be observed that the absorption spectra of quinizarin in phosphate buffer present a maximum at $470 \mathrm{~nm}$. As the polarity of the solvents decreases, the shape of quinizarin spectrum changes and new peaks and / or shoulders appears. Also, the absorption maximum is shifted to higher wavelength with the decrease of the solvents polarity (Fig. 9b). The absorption spectrum of quinizarin in SDS micelles is quite similar with the spectra in polar solvents like methanol and ethanol and different from the spectra in a non-polar solvent such as toluene. Also, the relative polarity of quinizarin molecule in SDS micelles has a value $\left(\varepsilon_{\mathrm{Q}-\mathrm{SDS}} \sim 27.5\right)$ characteristic for polar solvents, such as methanol and ethanol. It is well known that micelles present an increasing polarity gradient from the core to the surface of the micelles. ${ }^{48}$ As the absorption spectrum of quinizarin in SDS micelles reproduces the characteristics of the spectra in polar solvents, we can say that quinizarin molecules are located in an aqueous microenvironment similar to methanol and ethanol. Hence, it can be deduced that quinizarin molecules are solubilized in the hydrophilic region rather than the hydrophobic region of micelles. This location in the outer portion of micelle close to micelle water interface can be explained by the structure of quinizarin molecule: a rigid, planar anthraquinone substituted by uncharged hydrophilic groups, which can be involved in hydrogen bonds with water molecules. ${ }^{49,50}$ Studies regarding the solubilization of quinizarin in anionic, cationic, nonionic and cationic gemini surfactants indicated that the straight chain surfactants were better solubilizers than alkyl aryl surfactants, the solubilization increases with the temperature and is higher for gemini surfactants than that of DTAB and quinizarin molecules are located just below the head group region of the surfactant micelles. ${ }^{49,50}$

\section{Conclusions}

This paper presents the results regarding the interaction of quinizarin with SDS micelles using spectrophotometric and conductometric techniques. The binding constant and partition coefficient values indicate a strong interaction between quinizarin and SDS micelles. The positive values of $\Delta \mathrm{S}^{0}$ and $\Delta \mathrm{H}^{0}$ indicate that both binding and partition processes are entropy controlled over the range of studied temperatures and the hydrophobic interactions are dominant. Regarding the position of quinizarin molecule in SDS micelles, the changes of absorption spectra of quinizarin in solvents with different polarities suggest that quinizarin molecule are located in a comparatively polar environment at the outer hydrophilic region of micelles.

The anthraquinone chromophore of quinizarin is present in the structure of widely used drugs in the treatment of different types of cancers. Even if the prevailing mechanism is the interaction with DNA, these drug molecules must pass the cell and nuclear membranes before interacting with DNA. The understanding of molecular interactions between drugs and biological membranes are 
important for medical research because these interactions are connected with the pharmacological activity of drugs. The present results using simple surfactant micelles as biomimetic model membranes give useful information regarding the interaction of drug molecules with biological membranes which will allow the rational design of new more efficient therapeutic agents and drug delivery systems. However, further more detailed investigations using distinct model membranes (i.e., liposomes with different lipid composition, supported lipid bilayers) are necessary for better understanding of the interaction mechanism.

\section{References}

1. G. Zengin, N.S. Degirmenci, L. Alpsoy, A. Aktumsek, Hum. Exp. Toxicol. 2016, 35, 544-553.

DOI:10.1177/0960327115595687

2. S. Rossi, C. Tabolacci, A. Lentini, B. Provenzano, F. Carlomosti, S. Frezzotti, S. Beninati, Anticancer Res. 2010, 30, 445-450.

3. Agudelo D, Bourassa P, Bérubé G, Tajmir-Riahi HA, J. Photochem. Photobiol. B 2016, 158, 274-279.

DOI:10.1016/j.jphotobiol.2016.02.032

4. G. Minotti, P. Menna, E. Salvatorelli, G. Cairo, L. Gianni, Pharmacol. Rev. 2004, 56, 185-229. DOI:10.1124/pr.56.2.6

5. C. Pérez-Arnaiz, N. Busto, J. M. Leal, B. Garcia, J. Phys. Chem. B 2014, 118, 1288-1295. DOI:10.1021/jp411429g

6. S. Agarwal, D. K. Jangir, R. Mehrotra, J. Photochem. Photobiol. B 2013, 120, 177-182. DOI:10.1016/j.jphotobiol.2012.11.001

7. M. Enache, E. Volanschi, Rev. Roumaine Chim. 2005, 50, 131-140.

8. J. Bhattacharyya, A. Basu, G. S. Kumar, J. Chem. Thermodynamics 2014, 75, 45-51. DOI:10.1016/j.jct.2014.04.015

9. P. S. Guin, S. Das, P. C. Mandal, J. Solution Chem. 2011, 40, 492-501. DOI:10.1007/s10953-011-9654-X

10. M. B. Gholivand, S. Kashanian, H. Peyman, H. Roshanfekr, Eur. J. Med. Chem. 2011, 46, 2630-2638.

DOI:10.1016/j.ejmech.2011.03.034

11. V. Verebova, J. Adamcik, P. Danko, D. Podhradsky, P. Miškovsky, J. Stanicova, Biochem. Biophys. Res. Commun. 2014, 444, 50-55. DOI:10.1016/j.bbrc.2014.01.007

12. P. Das, D. Bhattacharya, P. Karmakar, S. Das, RSC Adv. 2015, 5, 73099-73111. DOI:10.1039/C5RA07805A

13. C. Batchelor-McAuley, I. B. Dimov, L. Aldous, R. G. Compton, Proc. Natl. Acad. Sci. U.S.A 2011, 108, 19891-19895.

DOI:10.1073/pnas.1113615108

14. M. Enache, C. Bendic, E. Volanschi, Bioelectrochemistry 2008, 72, 10-20. DOI:10.1016/j.bioelechem.2007.10.001

15. M. A. G. Trindade, U. Bilibio, M. V. B. Zanoni, Fuel 2014, 136, 201-207. DOI:10.1016/j.fuel.2014.07.044

16. C. Bourgaux, P. Couvreur, J. Control. Release 2014, 190, 127138. DOI:10.1016/j.jconrel.2014.05.012

17. M.-T. Dimanche-Boitrel, O. Meurette, A. Rebillard, S. Lacour, Drug Resist. Updat. 2005, 8, 5-14.

DOI:10.1016/j.drup.2005.02.003
18. S. Roy, P. S. Sengupta, P. S. Guin, Chem. Phys. Lett. 2018, 694, 7-13. DOI:10.1016/j.cplett.2018.01.029

19. A. D. Saraf, S. Sharma, S. Sachar, Langmuir 2018, 34, 1462414632. DOI:10.1021/acs.langmuir.8b02814

20. T. S. Banipal, R. Kaur, P. K. Banipal, J. Mol. Liq. 2018, 255, 113-121. DOI:10.1016/j.molliq.2018.01.089

21. N. Erdinc, S. Gokturk, M. Tuncay, J. Pharm. Sci. 2004, 93, 1566-1576. DOI:10.1002/jps.20056

22. A. Datta, S. Roy, P. Mondal, P. S. Guin, J. Mol. Liq. 2016, 219, 1058-1064. DOI:10.1016/j.molliq.2016.04.049

23. O. Cudina, J. Brboric, I. Jankovic, K. Karljikovic-Rajic, S. Vladimirov, Colloids Surf. B: Biointerfaces 2008, 65, 80-84. DOI:10.1016/j.colsurfb.2008.03.002

24. Zahari Vinarov, V. Katev, D. Radeva, S. Tcholakova and N. D. Denkov, Drug Dev. Ind. Pharm. 2017, 44, 677-686. DOI:10.1080/03639045.2017.1408642

25. M. Enache, A. M. Toader, M. I. Enache, Molecules 2016, 21, 1356. DOI:10.3390/molecules21101356

26. M. Enache, S. Ionescu, E. Volanschi, J. Mol. Liq. 2015, 208, 333-341. DOI:10.1016/j.molliq.2015.05.006

27. M. Savko, S. Kascakova, P. Gbur, P. Miskovsky, J. Ulicny, J. Mol. Struct. THEOCHEM 2007, 823, 78-86.

DOI:10.1016/j.theochem.2007.08.032

28. E. Fuguet, C. Rafols, M. Roses, E. Bosch, Anal. Chim. Acta 2005, 548, 95-100. DOI:10.1016/j.aca.2005.05.069

29. H. A. Benesi, J. H. Hildebrand, J. Am. Chem. Soc. 1949, 71, 2703-2707. DOI:10.1021/ja01176a030

30. Y. Shiraishi, S. Sumiya, Y. Kohno, T. Hirai, J. Org. Chem. 2008, 73, 8571-8574. DOI:10.1021/jo8012447

31. M. Enache, A. M. Toader, J. Surfact. Deterg. 2018, 21, 31-41. DOI:10.1002/jsde.12014

32. A. Das, S. Roy, P. Mondal, A. Datta, K. Mahali, G. Loganathan, D. Dharumadurai, P.S. Sengupta, M.A. Akbarsha, P.S. Guin, RSC Adv. 2016, 6, 28200-28212.

DOI:10.1039/C6RA00062B

33. L. Sepulveda, E. Lissi, F. Quina, Adv. Colloid Int. Sci. 1986, 25, 1-57. DOI:10.1016/0001-8686(86)80001-X

34. H. Kawamura, M. Manabe, Y. Miyamoto, Y. Fujita, S. Tokunaga, J. Phys. Chem. 1989, 93, 5536-5540.

DOI:10.1021/j100351a042

35. M. Usman, M. A. Rashid, A. Mansha, M. Siddiq, Thermochim. Acta 2013, 573, 18-24. DOI:10.1016/j.tca.2013.08.014

36. F. Akhtar, M. A. Hoque, M. A. Khan, J. Chem. Thermodyn. 2008, 40, 1082-1086. DOI:10.1016/j.jct.2008.03.001

37. M.A. Hoque, M. A. Khan, M. D. Hossain, J. Chem. Thermodyn. 2013, 60, 71-75. DOI:10.1016/j.jct.2013.01.001

38. M. Usman, M. Siddiq, Spectrochim. Acta A: Mol. Biomol. Spectrosc. 2013, 113, 182-190.

DOI:10.1016/j.saa.2013.04.089

39. M. Rahman, M. A. Khan, M. A. Rubb, M. A. Hoque, J. Mol. Liq. 2016, 223, 716-724. DOI:10.1016/j.molliq.2016.08.049

40. A. D. Mudawadkar, T. J. Patil, Chem. Sci. Trans. 2016, 5, 149162.

41. T. Sasaki, H. Michihiro, S. Jun, N. Kenji, Bull. Chem. Soc. Jpn. 1975, 48, 1397-1403. DOI:10.1246/bcsj.48.1397

42. M. A. Bahri, M. Hoebeke, A. Grammenosb, L. Delanaye, N. 
Vandewalle, A. Seret, Colloids Surf. A Physicochem. Eng. Asp. 2006, 290, 206-212. DOI:10.1016/j.colsurfa.2006.05.021

43. A. Ali, S. Uzair, N. A. Malik, M. Ali, J. Mol. Liq. 2014, 196, 395-403. DOI:10.1016/j.molliq.2014.04.013

44 C. O. Rangel-Yagui, A. Pessoa Jr., L. C. Tavares, J. Pharm. Pharm. Sci. 2005, 8, 147-165.

45. J. Oakes, P. Gratton, Color. Technol. 2003, 119, 91-99. DOI:10.1111/j.1478-4408.2003.tb00156.x

46. A. R. Tehrani-Bagha, K. Holmberg, Materials 2013, 6, 580608. DOI:10.3390/ma6020580
47. A. Choucair, A.Eisenberg, J. Am. Chem. Soc. 2003, 125, 11993- 2000. DOI:10.1021/ja036667d

48 E. Blatt, K. P. Ghiggin, J. Chem. Soc. Faraday Trans. I 1981, 77, 2551-2558. DOI:10.1039/f19817702551

49. A. R. Tehrani-Bagha, R. G. Singh, K. Holmberg, J. Colloid Interface Sci. 2012, 376, 112-118.

DOI:10.1016/j.jcis.2012.02.016

50. A. R. Tehrani-Bagha, R. G. Singh, K. Holmberg, Colloids Surf. A Physicochem. Eng. Asp. 2013, 417, 133-139.

DOI:10.1016/j.colsurfa.2012.10.006

\section{Povzetek}

Preiskava medsebojnega delovanja kvinizarina (Q), ki je podoben osrednji enoti različnih zdravil proti raku, in anionskih micel natrijevega dodecil sulfata (SDS), je bila izvedena $\mathrm{z}$ meritvami absorpcije in prevodnosti v $0,1 \mathrm{M}$ fosfatnem pufru s pH 7,4 in v temperaturnem območju 293.15-323,15 K. Vrednosti vezavne konstante $\left(\mathrm{K}_{\mathrm{b}}\right)$, porazdelitvenega koeficienta $\left(\mathrm{K}_{\mathrm{x}}\right)$ in ustrezni termodinamični parametri (Gibbsova prosta energija, entalpija, entropija) za vezavo in porazdelitev kvinizarina med vodno raztopino in micelami površinsko aktivne snovi so bile določene in obravnavane $\mathrm{v}$ smislu možnih medmolekulskih interakcij. Vrednosti kritične micelne koncentracije (CMC) in stopnje ionizacije ( $\alpha)$ za SDS v odsotnosti in prisotnosti kvinizarina so bile določene iz kondometrične študije. Primerjava absorpcijskih spektrov kvinizarina v micelah SDS s spektri v različnih topilih je pokazala, da se molekule kvinizarina nahajajo v hidrofilnem območju SDS micel. Trend sprememb Gibbsove proste energije, entalpije in entropije s temperaturo kaže, da sta oba procesa,vezava in porazdelitev, spontana in entropijsko vodena. Poleg tega so hidrofobne interakcije glavne gonilne sile, ki sodelujejo v procesih vezave in porazdeljevanja.

Except when otherwise noted, articles in this journal are published under the terms and conditions of the Creative Commons Attribution 4.0 International License 